4

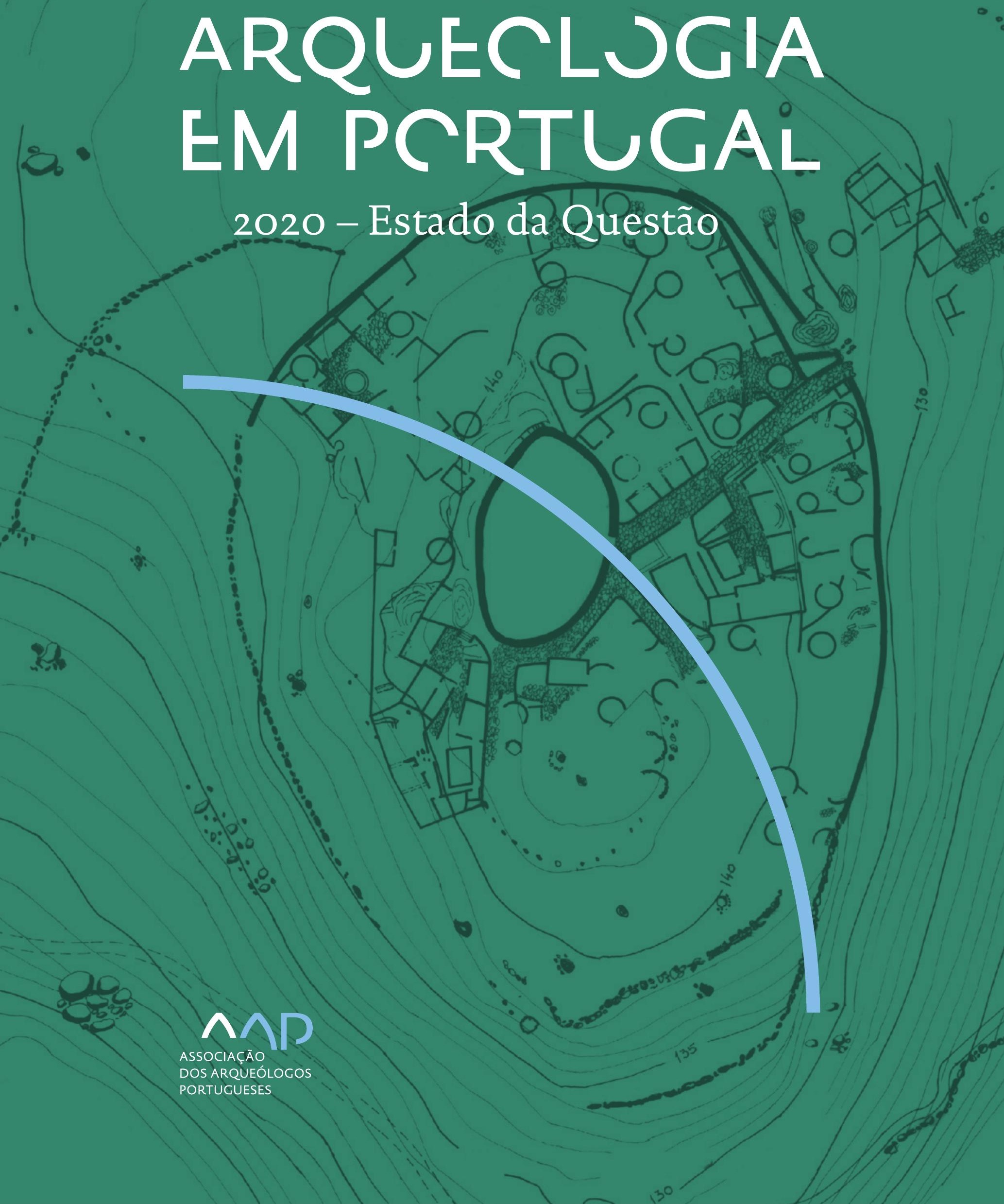


Coordenação editorial: José Morais Arnaud, César Neves e Andrea Martins Design gráfico: Flatland Design

AAP - ISBN: 978-972-9451-89-8

CITCEM - ISBN: 978-989-8970-25-1

Associação dos Arqueólogos Portugueses e CITCEM

Lisboa, 2020

O conteúdo dos artigos é da inteira responsabilidade dos autores. Sendo assim a Associação dos Arqueólogos Portugueses declina qualquer responsabilidade por eventuais equívocos ou questões de ordem ética e legal.

Desenho de capa:

Planta do castro de Monte Mozinho (Museu Municipal de Penafiel).

\section{$\hat{\wedge} \mathrm{P}$}

DOS ARQUEÓLOGOS PORTUGUESES

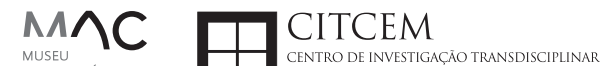
MUSEU
ARQUELLÓGICO
DO CARMO
U.PORTO

FLUP FACULDADE DE LETRAS
UNIVERSIDADE DO PORTO

Apoio

EC para a Ciência 


\section{Índice}

15 Prefácio

José Morais Arnaud

\section{Historiografia e Teoria}

17 Território, comunidade, memória e emoção: a contribuição da história da arqueologia (algumas primeiras e breves reflexões)

Ana Cristina Martins

25 Como descolonizar a arqueologia portuguesa?

Rui Gomes Coelho

41 Arqueologia e Modernidade: uma revisitação pessoal e breve de alguns aspetos da obra homónima de Julian Thomas de 2004

Vítor Oliveira Jorge

57 Dados para a História das Mulheres na Arqueologia portuguesa, dos finais do século XIX aos inícios do século XX: números, nomes e tabelas

Filipa Dimas / Mariana Diniz

73 Retractos da arqueologia portuguesa na imprensa: (in)visibilidades no feminino

Catarina Costeira / Elsa Luís

85 Arqueologia e Arqueólogos no Norte de Portugal Jacinta Bugalhão

101 Vieira Guimarães (1864-1939) e a arqueologia em Tomar: uma abordagem sobre o território e as gentes

João Amendoeira Peixoto / Ana Cristina Martins

115 Os memoráveis? A arqueologia algarvia na imprensa nacional e regional na presente centúria (2001-2019): características, visões do(s) passado(s) e a arqueologia

enquanto marca

Frederico Agosto / João Silva

129 A Evolução da Arqueologia Urbana e a Valorização Patrimonial no Barlavento Algarvio: Os casos de Portimão e Silves

Artur Mateus / Diogo Varandas / Rafael Boavida

\section{Gestão, Valorização e Salvaguarda do Património}

145 O Caderno Reivindicativo e as condições de trabalho em Arqueologia Miguel Rocha / Liliana Matias Carvalho / Regis Barbosa / Mauro Correia / Sara Simões / Jacinta Bugalhão / Sara Brito / Liliana Veríssimo Carvalho / Richard Peace / Pedro Peça / Cézer Santos

155 Os Estudos de Impacte Patrimonial como elemento para uma estratégia sustentável de minimização de impactes no âmbito de reconversões agrícolas Tiago do Pereiro

165 Salvaguarda de Património arqueológico em operações florestais: gestão e sensibilização Filipa Bragança / Gertrudes Zambujo / Sandra Lourenço / Belém Paiva / Carlos Banha / Frederico Tatá Regala / Helena Moura / Jacinta Bugalhão / João Marques / José Correia / Pedro Faria / Samuel Melro

179 Os valores do Património: uma investigação sobre os Sítios Pré-históricos de Arte Rupestre do Vale do Rio Côa e de Siega Verde José Paulo Francisco 
189 Conjugando recursos arqueológicos e naturais para potenciar as visitas ao Geoparque Litoral de Viana do Castelo (Noroeste de Portugal)

Hugo A. Sampaio / Ana M.S. Bettencourt / Susana Marinho / Ricardo Carvalhido

203 Áreas de Potencial Arqueológico na Região do Médio Tejo: Modelo Espacial Preditivo Rita Ferreira Anastácio / Ana Filipa Martins / Luiz Oosterbeek

223 Património Arqueológico e Gestão Territorial: O contributo da Arqueologia para a revisão do PDM de Avis

Ana Cristina Ribeiro

237 A coleção arqueológica do extinto Museu Municipal do Porto - Origens, Percursos e Estudos

Sónia Couto

251 Valpaços - uma nova carta arqueológica

Pedro Pereira / Maria de Fátima Casares Machado

263 Arqueologia na Cidade de Peniche

Adriano Constantino / Luís Rendeiro

273 Arqueologia Urbana: a cidade de Lagos como caso de Estudo Cátia Neto

285 Estratégias de promoção do património cultural subaquático nos Açores. O caso da ilha do Faial

José Luís Neto / José Bettencourt / Luís Borges / Pedro Parreira

297 Carta Arqueológica da Cidade Velha: Uma primeira abordagem

Jaylson Monteiro / Nireide Tavares / Sara da Veiga / Claudino Ramos / Edson Brito /

Carlos Carvalho / Francisco Moreira / Adalberto Tavares

311 Antropologia Virtual: novas metodologias para a análise morfológica e funcional Ricardo Miguel Godinho / Célia Gonçalves

\section{Didáctica da Arqueologia}

327 Como os projetos de Arqueologia podem contribuir para uma comunidade culturalmente mais consciente Alexandra Figueiredo / Claúdio Monteiro / Adolfo Silveira / Ricardo Lopes

337 Educação Patrimonial - Um cidadão esclarecido é um cidadão ativo! Ana Paula Almeida

351 A aproximação da Arqueologia à sala de aula: um caso de estudo no $3^{\circ}$ ciclo do Ensino Básico Luís Serrão Gil

363 Arqueologia 3.o - Pensar e comunicar a Arqueologia para um futuro sustentável Mónica Rolo

377 “Conversa de Arqueólogos" - Divulgar a Arqueologia em tempos de Pandemia Diogo Teixeira Dias

389 Escola Profissional de Arqueologia: desafios e oportunidades Susana Nunes / Dulcineia Pinto / Júlia Silva / Ana Mascarenhas

399 Os Museus de Arqueologia e os Jovens: a oferta educativa para o público adolescente Beatriz Correia Barata / Leonor Medeiros

411 O museu universitário como mediador entre a ciência e a sociedade: o exemplo da secção de arqueologia no Museu de História Natural e da Ciência da Universidade do Porto (MHNC-UP)

Rita Gaspar 
421 Museu de Lanifícios: Real Fábrica de Panos. Atividades no âmbito da Arqueologia Beatriz Correia Barata / Rita Salvado

427 Arqueologia Pública e o caso da localidade da Mata (Torres Novas) Cláudia Manso / Ana Rita Ferreira / Cristiana Ferreira / Vanessa Cardoso Antunes

431 Do sítio arqueológico ao museu: um percurso (também) didático Lídia Fernandes

447 Estão todos convidados para a Festa! E para dançar também... O projecto do Serviço Educativo do Museu Arqueológico do Carmo na $5^{\underline{a}}$ Edição da Festa da Arqueologia Rita Pires dos Santos

459 O “Clã de Carenque”, um projeto didático de arqueologia Eduardo Gonzalez Rocha

469 Mediação cultural: peixe que puxa carroça nas Ruínas Romanas de Troia Inês Vaz Pinto / Ana Patrícia Magalhães / Patrícia Brum / Filipa Santos

481 Didática Arqueológica, experiências do Projeto Mértola Vila Museu Maria de Fátima Palma / Clara Rodrigues / Susana Gómez / Lígia Rafael

\section{Arte Rupestre}

497 Os inventários de arte rupestre em Portugal Mila Simões de Abreu

513 O projeto FIRST-ART - conservação, documentação e gestão das primeiras manifestações de arte rupestre no Sudoeste da Península Ibérica: as grutas do Escoural e Maltravieso Sara Garcês / Hipólito Collado / José Julio García Arranz / Luiz Oosterbeek / António Carlos Silva / Pierluigi Rosina / Hugo Gomes / Anabela Borralheiro Pereira / George Nash / Esmeralda Gomes / Nelson Almeida / Carlos Carpetudo

523 Trabalhos de documentação de arte paleolítica realizados no âmbito do projeto PalæoCôa André Tomás Santos / António Fernando Barbosa / Luís Luís / Marcelo Silvestre / Thierry Aubry

537 Imagens fantasmagóricas, silhuetas elusivas: as figuras humanas na arte do Paleolítico Superior da região do Côa Mário Reis

$55^{1}$ Os motivos zoomórficos representados nas placas de tear de Vila Nova de São Pedro (Azambuja, Portugal) Andrea Martins / César Neves / José M. Arnaud / Mariana Diniz

571 Arte Rupestre do Monte de Góios (Lanhelas, Caminha). Síntese dos resultados dos trabalhos efectuados em 2007-2009 Mário Varela Gomes

599 Gravuras rupestres de barquiformes no Monte de S. Romão, Guimarães, Noroeste de Portugal Daniela Cardoso

613 Círculos segmentados gravados na Bacia do Rio Lima (Noroeste de Portugal): contributos para o seu estudo Diogo Marinho / Ana M.S. Bettencourt / Hugo Aluai Sampaio

631 Equídeos gravados no curso inferior do Rio Mouro, Monção (NW Portugal). Análise preliminar Coutinho, L.M. / Bettencourt, A.M.S / Sampaio, Hugo A.S

645 Paletas na Arte Rupestre do Noroeste de Portugal. Inventário preliminar Bruna Sousa Afonso / Ana M. S. Bettencourt / Hugo A. Sampaio 


\section{Pré-História}

661 O projeto Miño/Minho: balanço de quatro anos de trabalhos arqueológicos Sérgio Monteiro-Rodrigues / João Pedro Cunha-Ribeiro / Eduardo Méndez-Quintas / Carlos Ferreira / Pedro Xavier / José Meireles / Alberto Gomes / Manuel Santonja / Alfredo Pérez-González

677 A ocupação paleolítica da margem esquerda do Baixo Minho: a indústria lítica do sítio de Pedreiras 2 (Monção, Portugal) e a sua integração no contexto regional Carlos Ferreira / João Pedro Cunha-Ribeiro / Sérgio Monteiro-Rodrigues / Eduardo Méndez-Quintas / Pedro Xavier / José Meireles / Alberto Gomes / Manuel Santonja / Alfredo Pérez-González

693 O sítio acheulense do Plistocénico médio da Gruta da Aroeira Joan Daura / Montserrat Sanz / Filipa Rodrigues / Pedro Souto / João Zilhão

703 As sociedades neandertais no Barlavento algarvio: modelos preditivos com recurso aos SIG

Daniela Maio

715 A utilização de quartzo durante o Paleolítico Superior no território dos vales dos rios Vouga e Côa

Cristina Gameiro / Thierry Aubry / Bárbara Costa / Sérgio Gomes / Luís Luís / Carmen Manzano / André Tomás Santos

733 Uma perspetiva diacrónica da ocupação do concheiro do Cabeço da Amoreira (Muge, Portugal) a partir da tecnologia lítica Joana Belmiro / João Cascalheira / Célia Gonçalves

745 Novos dados sobre a Pré-história Antiga no concelho de Palmela. A intervenção arqueológica no sítio do Poceirão I

Michelle Teixeira Santos

757 Problemas em torno de Datas Absolutas Pré-Históricas no Norte do Alentejo Jorge de Oliveira

771 Povoamento pré-histórico nas áreas montanhosas do NO de Portugal: o Abrigo 1 de Vale de Cerdeira Pedro Xavier / José Meireles / Carlos Alves

783 Apreciação do povoamento do Neolítico Inicial na Baixa Bacia do Douro. A Lavra I (Serra da Aboboreira) como caso de estudo Maria de Jesus Sanches

797 O Processo de Neolitização na Plataforma do Mondego: os dados do Sector C do Outeiro dos Castelos de Beijós (Carregal do Sal)

João Carlos de Senna-Martinez / José Manuel Quintã Ventura / Andreia Carvalho / Cíntia Maurício

823 Novos trabalhos na Lapa da Bugalheira (Almonda, Torres Novas) Filipa Rodrigues / Pedro Souto / Artur Ferreira / Alexandre Varanda / Luís Gomes / Helena Gomes / João Zilhão

837 A pedra polida e afeiçoada do sítio do Neolítico médio da Moita do Ourives (Benavente, Portugal)

César Neves

857 Casal do Outeiro (Encarnação, Mafra): novos contributos para o conhecimento do povoamento do Neolítico final na Península de Lisboa.

Cátia Delicado / Carlos Maneira e Costa / Marta Miranda / Ana Catarina Sousa

873 Stresse infantil, morbilidade e mortalidade no sítio arqueológico do Neolítico Final/ Calcolítico ( $4^{\circ}$ e $3^{\circ}$ milénio a.C.) do Monte do Carrascal 2 (Ferreira do Alentejo, Beja) Liliana Matias de Carvalho / Sofia N. Wasterlain 
885 Come together: O Conjunto Megalítico das Motas (Monção, Viana do Castelo) e as expressões Campaniformes do Alto Minho Ana Catarina Basílio / Rui Ramos

899 Trabalhos arqueológicos no sítio Calcolítico da Pedreira do Poio Carla Magalhães / João Muralha / Mário Reis / António Batarda Fernandes

913 O sítio arqueológico de Castanheiro do Vento. Da arquitectura do sítio à arquitectura de um território João Muralha Cardoso

925 Estudo zooarqueológico das faunas do Calcolítico final de Vila Nova de São Pedro (Azambuja, Portugal): Campanhas de 2017 e 2018 Cleia Detry / Ana Catarina Francisco / Mariana Diniz / Andrea Martins / César Neves / José Morais Arnaud

943 As faunas depositadas no Museu Arqueológico do Carmo provenientes de Vila Nova de São Pedro (Azambuja): as campanhas de 1937 a 1967 Ana Catarina Francisco / Cleia Detry / César Neves / Andrea Martins / Mariana Diniz / José Morais Arnaud

959 Análise funcional de material lítico em sílex do castro de Vila Nova de S. Pedro (Azambuja, Portugal): uma primeira abordagem Rafael Lima

971 O recinto da Folha do Ouro 1 (Serpa) no contexto dos recintos de fossos calcolíticos alentejanos

António Carlos Valera / Tiago do Pereiro / Pedro Valério / António M. Monge Soares

\section{Proto-História}

987 Produção de sal marinho na Idade do Bronze do noroeste Português. Alguns dados para uma reflexão

Ana M. S. Bettencourt / Sara Luz / Nuno Oliveira / Pedro P. Simões / Maria Isabel C. Alves / Emílio Abad-Vidal

1001 A estátua-menir do Pedrão ou de São Bartolomeu do Mar (Esposende, noroeste de Portugal) no contexto arqueológico da fachada costeira de entre os rios Neiva e Cávado Ana M. S. Bettencourt / Manuel Santos-Estévez / Pedro Pimenta Simões / Luís Gonçalves

1015 O Castro do Muro (Vandoma/Baltar, Paredes) - notas para uma biografia de ocupação da Idade do Bronze à Idade Média

Maria Antónia D. Silva / Ana M. S. Bettencourt / António Manuel S. P. Silva / Natália Félix

1031 Do Bronze Final à Idade Média - continuidades e hiatos na ocupação de Povoados em Oliveira de Azeméis João Tiago Tavares / Adriaan de Man

1041 As faunas do final da Idade do Bronze no Sul de Portugal: leituras desde o Outeiro do Circo (Beja)

Nelson J. Almeida / Íris Dias / Cleia Detry / Eduardo Porfírio / Miguel Serra

1055 A Espada do Monte das Oliveiras (Serpa) - uma arma do Bronze Pleno do Sudoeste Rui M. G. Monge Soares / Pedro Valério / Mariana Nabais / António M. Monge Soares

1065 São Julião da Branca (Albergaria-a-Velha) - Investigação e valorização de um povoado do Bronze Final

António Manuel S. P. Silva / Paulo A. P. Lemos / Sara Almeida e Silva / Edite Martins de Sá

1083 Do castro de S. João ao Mosteiro de Santa Clara: notícia de uma intervenção arqueológica, em Vila do Conde Rui Pinheiro 
1095 O castro de Ovil (Espinho), um quarto de século de investigação - resultados e questões em aberto

Jorge Fernando Salvador / António Manuel S. P. Silva

1111 O Castro de Salreu (Estarreja), um povoado proto-histórico no litoral do Entre Douro e Vouga

Sara Almeida e Silva / António Manuel S. P. Silva / Paulo A. P. Lemos / Edite Martins de Sá

1127 Castro de Nossa Senhora das Necessidades (Sernancelhe): uma primeira análise artefactual Telma Susana O. Ribeiro

${ }_{1141}$ A cividade de Bagunte. O estado atual da investigação Pedro Brochado de Almeida

1153 Zoomorfos na cerâmica da Idade do Ferro no NW Peninsular: inventário, cronologias e significado Nuno Oliveira / Cristina Seoane

1163 Vasos gregos em Portugal: diferentes maneiras de contar a história do intercâmbio cultural na Idade do Ferro

Daniela Ferreira

1175 Os exotica da necrópole da Idade do Ferro do Olival do Senhor dos Mártires (Alcácer do Sal) no seu contexto regional

Francisco B. Gomes

\section{Antiguidade Clássica e Tardia}

1191 O uso de madeira como combustível no sítio da Quinta de Crestelos (Baixo Sabor): da Idade do Ferro à Romanização Filipe Vaz / João Tereso / Sérgio Simões Pereira / José Sastre / Javier Larrazabal Galarza / Susana Cosme / José António Pereira / Israel Espi

1207 Cultivos de Época Romana no Baixo Sabor: continuidade em tempos de mudança? João Pedro Tereso / Sérgio Simões Pereira / Filipe Santos / Luís Seabra / Filipe Vaz

1221 A casa romana na Hispânia: aplicação dos modelos itálicos nas províncias ibéricas Fernanda Magalhães / Diego Machado / Manuela Martins

1235 As pinturas murais romanas da Rua General Sousa Machado, n. ${ }^{5}$ 1, Chaves José Carvalho

1243 Trás do Castelo (Vale de Mir, Pegarinhos, Alijó) - Uma exploração agrícola romana do Douro

Tony Silvino / Pedro Pereira

1255 A sequência de ocupação no quadrante sudeste de Bracara Augusta: as transformações de uma unidade doméstica Lara Fernandes / Manuela Martins

1263 Os Mosaicos com decoração geométrica e geométrico-vegetalista dos sítios arqueológicos da área do Conuentus Bracaraugustanus. Novas abordagens quanto à conservação, restauro, decoração e datação Maria de Fátima Abraços / Licínia Wrench

1277 “Casa Romana” do Castro de São Domingos (Cristelos, Lousada): Escavação, Estudo e Musealização Paulo André de P. Lemos

1291 A arqueobotânica no Castro de Guifões (Matosinhos, Noroeste de Portugal): O primeiro estudo carpológico

Luís Seabra / Andreia Arezes / Catarina Magalhães / José Varela / João Pedro Tereso 
1305 Um Horreum Augustano na Foz do Douro (Monte do Castelo de Gaia, Vila Nova de Gaia) Rui Ramos

1311 Ponderais romanos na Lusitânia: padrões, formas, materiais e contextos de utilização Diego Barrios Rodríguez

1323 Um almofariz centro-itálico na foz do Mondego

Marco Penajoia

1335 Estruturas romanas de Carnide - Lisboa Luísa Batalha / Mário Monteiro / Guilherme Cardoso

1347 O contexto funerário do sector da "necrópole NO" da Rua das Portas de S. Antão (Lisboa): o espaço, os artefactos, os indivíduos e a sua interconectividade na interpretação do passado Sílvia Loja, José Carlos Quaresma, Nelson Cabaço, Marina Lourenço, Sílvia Casimiro, Rodrigo Banha da Silva, Francisca Alves-Cardoso

${ }_{1361}$ Povoamento em época Romana na Amadora - resultados de um projeto pluridisciplinar Gisela Encarnação / Vanessa Dias

1371 A Arquitectura Residencial em Mirobriga (Santiago do Cacém): contributo a partir de um estudo de caso Filipe Sousa / Catarina Felício

${ }_{1385}$ O fim do ciclo. Saneamento e gestão de resíduos nos edifícios termais de Mirobriga (Santiago do Cacém)

Catarina Felício / Filipe Sousa

1399 Balsa, Topografia e Urbanismo de uma Cidade Portuária Vítor Silva Dias / João Pedro Bernardes / Celso Candeias / Cristina Tété Garcia

1413 No Largo das Mouras Velhas em Faro (2017): novas evidências da necrópole norte de Ossonoba e da sua ocupação medieval Ricardo Costeira da Silva / Paulo Botelho / Fernando Santos / Liliana Nunes

1429 Instrumentos de pesca recuperados numa fábrica de salga em Ossonoba (Faro) Inês Rasteiro / Ricardo Costeira da Silva / Paulo Botelho

1439 A Necrópole Romana do Eirô, Duas Igrejas (Penafiel): intervenção arqueológica de 2016 Laura Sousa / Teresa Soeiro

1457 Ritual, descarte ou afetividade? A presença de Canis lupus familiaris na Necrópole Noroeste de Olisipo (Lisboa)

Beatriz Calapez Santos / Sofia Simões Pereira / Rodrigo Banha da Silva / Sílvia Casimiro / Cleia Detry / Francisca Alves Cardoso

1467 Dinâmicas económicas em Bracara na Antiguidade Tardia Diego Machado / Manuela Martins / Fernanda Magalhães / Natália Botica

1479 Cerâmicas e Vidros da Antiguidade Tardia do Edifício sob a Igreja do Bom Jesus (Vila Nova de Gaia) Joaquim Filipe Ramos

1493 Novos contributos para a topografia histórica de Mértola no período romano e na Antiguidade Tardia Virgílio Lopes

\section{8. Época Medieval}

1511 Cerâmicas islâmicas no Garb setentrional "português": algumas evidências e incógnitas Constança dos Santos / Helena Catarino / Susana Gómez / Maria José Gonçalves / Isabel Inácio / Gonçalo Lopes / Jacinta Bugalhão / Sandra Cavaco / Jaquelina Covaneiro / Isabel Cristina Fernandes / Ana Sofia Gomes 
1525 Contributo para o conhecimento da cosmética islâmica, em Silves, durante a Idade Média Rosa Varela Gomes

1537 Yábura e o seu território - uma análise histórico-arqueológica de Évora entre os séculos VIII-XII José Rui Santos

1547 A encosta sul do Castelo de Palmela - resultados preliminares da escavação arqueológica Luís Filipe Pereira / Michelle Teixeira Santos

1559 A igreja de São Lourenço (Mouraria, Lisboa): um conjunto de silos e de cerâmica medieval islâmica

Andreia Filipa Moreira Rodrigues

1571 O registo material de movimentações populacionais no Médio Tejo, durante os séculos XII-XIII. Dois casos de "sunken featured buildings", nos concelhos de Cartaxo e Torres Novas Marco Liberato / Helena Santos / Nuno Santos

1585 O nordeste transmontano nos alvores da Idade média. Notas para reflexão Ana Maria da Costa Oliveira

1601 Sepulturas escavadas na rocha do Norte de Portugal e do Vale do Douro: primeiros resultados do Projecto SER-NPVD

Mário Jorge Barroca / César Guedes / Andreia Arezes / Ana Maria Oliveira

1619 "Portucalem Castrum Novum" entre o Mediterrâneo e o Atlântico: o estudo dos materiais cerâmicos alto-medievais do arqueossítio da rua de D. Hugo, nํ. 5 (Porto) João Luís Veloso

1627 A Alta Idade Média na fronteira de Lafões: notas preliminares sobre a Arqueologia no Concelho de Vouzela

Manuel Luís Real / Catarina Tente

1641 Um conjunto cerâmico medieval fora de portas: um breve testemunho aveirense Susana Temudo

${ }_{1651}$ Os Lóios do Porto: uma perspetiva integrada no panorama funerário da Baixa Idade Média à Época Moderna em meios urbanos em Portugal

Ana Lema Seabra

1659 O Caminho Português Interior de Santiago como eixo viário na Idade Média Pedro Azevedo

1665 Morfologia Urbana: Um exercício em torno do Castelo de Ourém André Donas-Botto / Jaqueline Pereira

1677 Intervenção arqueológica na Rua Marquês de Pombal/Largo do Espírito Santo (Bucelas, Loures)

Florbela Estêvão / Nathalie Antunes-Ferreira / Dário Ramos Neves / Inês Lisboa

1691 O Cemitério Medieval do Poço do Borratém e a espacialidade funerária na cidade de Lisboa Inês Belém / Vanessa Filipe / Vasco Noronha Vieira / Sónia Ferro / Rodrigo Banha da Silva

1705 Um Espaço Funerário Conventual do séc. XV em Lisboa: o caso do Convento de São Domingos da Cidade Sérgio Pedroso / Sílvia Casimiro / Rodrigo Banha da Silva / Francisca Alves Cardoso

\section{9. Época Moderna e Contemporânea}

1721 Arqueologia Moderna em Portugal: algumas reflexões críticas em torno da quantificação de conjuntos cerâmicos e suas inferências históricas e antropológicas Rodrigo Banha da Silva / André Bargão / Sara da Cruz Ferreira

1733 Faianças de dois contextos entre os finais do século XVI e XVIII do Palácio dos Condes de Penafiel, Lisboa

Martim Lopes / Tomás Mesquita 
1747 Um perfil de consumo do século XVIII na foz do Tejo: O caso do Mercado da Ribeira, Lisboa Sara da Cruz Ferreira / Rodrigo Banha da Silva / André Bargão

1761 Os Cachimbos dos Séculos XVII e XVIII do Palácio Mesquitela e Convento dos Inglesinhos (Lisboa)

Inês Simão / Marina Pinto / João Pimenta / Sara da Cruz Ferreira / André Bargão / Rodrigo Banha da Silva

1775 "Tomar os fumos da erua que chamão em Portugal erua sancta». Estudo de Cachimbos provenientes da Rua do Terreiro do Trigo, Lisboa

Miguel Martins de Sousa / José Pedro Henriques / Vanessa Galiza Filipe

1787 Cachimbos de Barro Caulínitico da Sé da Cidade Velha (República de Cabo Verde)

Rodrigo Banha da Silva / João Pimenta / Clementino Amaro

1801 Algumas considerações sobre espólio não cerâmico recuperado no Largo de Jesus (Lisboa) Carlos Boavida

1815 Adereços de vidro, dos séculos XVI-XVIII, procedentes do antigo Convento de Santana de Lisboa (anéis, braceletes e contas)

Joana Gonçalves / Rosa Varela Gomes / Mário Varela Gomes

1837 Da ostentação, luxo e poder à simplicidade do uso quotidiano: arqueologia e simbologia de joias e adornos da Idade Moderna Portuguesa Jéssica Iglésias

1849 Os amuletos em Portugal - dos objetos às superstições: o coral vermelho Alexandra Vieira

1865 Cerâmicas de Vila Franca de Xira nos séculos XV e XVI Eva Pires

1879 «Não passa por teu o que me pertence». Marcas de individualização associadas a faianças do Convento de Nossa Senhora de Aracoeli, Alcácer do Sal Catarina Parreira / Íris Fragoso / Miguel Martins de Sousa

1891 Cerâmica de Leiria: alguns focos de produção

Jaqueline Pereira / André Donas-Botto

1901 Os Fornos na Rua da Biquinha, em Óbidos Hugo Silva / Filipe Oliveira

1909 A casa de Pêro Fernandes, contador dos contos de D. Manuel I: o sítio arqueológico da Silha do Alferes, Seixal (século XVI) Mariana Nunes Ferreira

1921 O Alto da Vigia (Sintra) e a vigilância e defesa da costa Alexandre Gonçalves / Sandra Santos

1937 O contexto da torre sineira da Igreja de Santa Maria de Loures Paulo Calaveira / Martim Lopes

1949 A Necrópole do Hospital Militar do Castelo de São Jorge e as práticas funerárias na Lisboa de Época Moderna Susana Henriques / Liliana Matias de Carvalho / Ana Amarante / Sofia N. Wasterlain

1963 SAND - Sarilhos Grandes Entre dois Mundos: o adro da Igreja e a Paleobiologia dos ossos humanos recuperados

Paula Alves Pereira / Roger Lee Jesus / Bruno M. Magalhães

1975 Expansão urbana da vila de Cascais no século XVII e XVIII: a intervenção arqueológica na Rua da Vitória no 15 a 17

Tiago Pereira / Vanessa Filipe

1987 Novos dados para o conhecimento do Urbanismo de Faro em época Moderna Ana Rosa 
1995 Um exemplo de Arqueologia Urbana em Alcoutim: o Antigo Edifício dos CTT Marco Fernandes / Marta Dias / Alexandra Gradim / Virgílio Lopes / Susana Gómez Martínez

2007 Palácio dos Ferrazes (Rua das Flores/Rua da Vitória, Porto): a cocheira de Domingos Oliveira Maia

Francisco Raimundo

2021 As muitas vidas de um edifício urbano: História, Arqueologia e Antropologia no antigo Recreatório Paroquial de Penafiel Helena Bernardo / Jorge Sampaio / Marta Borges

2035 O convento de Nossa Senhora da Esperança de Ponta Delgada: o contributo da arqueologia para o conhecimento de um monumento identitário João Gonçalves Araújo / N’Zinga Oliveira

2047 Arqueologia na ilha do Corvo... em busca da capela de Nossa Senhora do Rosário Tânia Manuel Casimiro / José Luís Neto / Luís Borges / Pedro Parreira

2059 Perdidos à vista da Costa. Trabalhos arqueológicos subaquáticos na Barra do Tejo Jorge Freire / José Bettencourt / Augusto Salgado

2071 Arqueologia marítima em Cabo Verde: enquadramento e primeiros resultados do projecto CONCHA

José Bettencourt / Adilson Dias / Carlos Lima / Christelle Chouzenoux / Cristóvão Fonseca / Dúnia Pereira / Gonçalo Lopes / Inês Coelho / Jaylson Monteiro / José Lima / Maria Eugénia Alves / Patrícia Carvalho / Tiago Silva

2085 Trabalhos arqueológicos na Cidade Velha (Ribeira Grande de Santiago, Cabo Verde): reflexões sobre um projecto de investigação e divulgação patrimonial André Teixeira / Jaylson Monteiro / Mariana Mateus / Nireide Tavares / Cristovão Fonseca / Gonçalo C. Lopes / Joana Bento Torres / Dúnia Pereira / André Bargão / Aurélie Mayer / Bruno Zélie / Carlos Lima / Christelle Chouzenoux / Inês Henriques / Inês Pinto Coelho / José Lima / Patrícia Carvalho / Tiago Silva

2103 A antiga fortificação de Quelba / Khor Kalba (E.A.U.). Resultados de quatro campanhas de escavações, problemáticas e perspectivas futuras Rui Carita / Rosa Varela Gomes / Mário Varela Gomes / Kamyar Kamyad

2123 Colónias para homens novos: arqueologia da colonização agrária fascista no noroeste ibérico Xurxo Ayán Vila / José Mạ . Señorán Martín 


\title{
NOVOS DADOS SOBRE A PRÉ-HISTÓRIA ANTIGA NO CONCELHO DE PALMELA. A INTERVENÇÃO ARQUEOLÓGICA NO SÍTIO DO POCEIRÃO I
}

\author{
Michelle Teixeira Santos ${ }^{1}$
}

\begin{abstract}
RESUMO
Apresentam-se os resultados da intervenção arqueológica realizada, em 2009, no sítio do Poceirão I (Palmela). Os trabalhos consistiram na realização de prospecção sistemática, por quadriculagem e de uma sondagem para diagnóstico do potencial arqueológico, registo de uma mancha de combustão e leitura estratigráfica. Os resultados obtidos permitiram individualizar dois Locus, uma dispersão considerável de artefactos de pedra lascada em sílex, quartzo e quartzitos, não tendo sido identificada a presença de cerâmicas. Porém, na área escavada Sondagem 1 - confirmou-se a forte destruição do sítio, a ausência de contextos antrópicos conservados e uma estratigrafia com reduzido potencial.

Partindo dos dados superficiais observados e do conjunto de espólio recolhido, o Poceirão I, parece corresponder a um sítio de habitat, ocupado por grupos de caçadores-recolectores do Mesolítico, da região interestuarina Tejo-Sado.

Palavras-Chave: Poceirão I, Mesolítico, Sado, Pedra Lascada, Caçadores-recolectores.
\end{abstract}

\begin{abstract}
Presentation of the results of the archaeological intervention at Poceirão I (Palmela) in 2009. The work consisted of conducting systematic prospecting using a grid and a survey to diagnose the archaeological potential, recording a combustion structure and stratigraphic reading. The results obtained, allowed to individualize two Locus, a considerable dispersion of chipped stone artifacts in flint, quartz and quartzite, but without pottery. However, the strong destruction of the site, the absence of preserved anthropic contexts and a stratigraphy with reduced potential was confirmed in the excavated area.

Based on the observed surface data and the materials exhumed, on Poceirão I settlement seems to have been occupied, during the Mesolithic, by groups of hunter-gatherers from the Tejo-Sado inter-estuarine region.

Keywords: Poceirão I, Mesolithic, Sado, Chipped stone, Hunter-gatherers.
\end{abstract}

\section{INTRODUÇÃO}

O sítio do Poceirão I - estação de ar livre -, localiza-se administrativamente no distrito de Setúbal, concelho de Palmela e na União de Freguesias de Poceirão e Marateca, no lugar do Poceirão, com as seguintes coordenadas geográficas, de acordo com o sistema de referência EPSG: 3763 (ETRS89/ PT-TMo6): Y - 115670 e X - 53100 e com $42 \mathrm{~m}$ de altitude. Ocupa uma área de antigo pinhal conhecida como «Pinhal Santos Jorge», desflorestada e em pousio, na margem lagunar do paleoestuário do Sado, junto da Ribeira da Agualva, a albufeira dos Vinte e Dois e a vala da Asseiceira, justamente entre as redes hidrográficas da ribeira das Enguias e da ribeira da Marateca, numa área plana e extensa com solos arenosos, a baixa altitude e sem condições naturais de defesa (Figura 1 e 2).

A sua centralidade neste ponto geográfico, com uma paisagem marcada pela presença de importantes cursos de água, afluentes do Tejo e do Sado, com um ambiente fluvial e uma diversidade de re-

1. Museu Municipal de Palmela; mtsantos@cm-palmela.pt 
cursos distintos do que hoje conhecemos terá sido determinante e vantajosa, para a permanência e sobrevivência neste território. Insere-se geológica e morfologicamente numa unidade caracterizada por um extenso planalto pliocénico com altitudes que variam entre os $20 \mathrm{~m}$ e $30 \mathrm{~m}$, subindo suavemente na vertente mais oriental até aos $125 \mathrm{~m}$, em que se formou o complexo greso-argiloso de Pegões, durante o Pliocénico marinho (Zbyszewski e Ferreira, 1968:5-9) (Figura 3).

A existência desta ocorrência era conhecida desde 1999, como depreendemos da informação associada a alguns materiais depositados no Museu Municipal, sem que houvesse correspondente informação na Carta Arqueológica do Concelho ou no Regulamento do Plano Director Municipal.

Esta ausência do Poceirão I no inventário do património arqueológico potenciou uma nova leitura do sítio, enquadrada nos trabalhos de prospecção na região de Palmela e Setúbal em 2005, coordenados por I. Fernandes e a signatária deste texto (Fernandes e Santos, 2012: 11-24), confirmando a existência de duas áreas distintas com concentração de materiais à superfície nomeadamente, núcleos de sílex, lamelas, lâminas e lascas residuais, raspadeiras de sílex, quartzo e quartzito e alguns seixos de quartzito talhados. Na fase do trabalho de gabinete (no tratamento, catalogação e inventário do espólio recolhido), não dispondo de informação mais detalhada decidimos, que o ano de 2005 seria a data de referência de recolha dos materiais - mantendo associado o apontamento em papel com data anterior -. O sítio integrou a Carta Arqueológica do Concelho e a Base de Dados Nacional - Endovélico, com o C.N.S. n.. 35463 (Figura 4).

Mais tarde, durante os trabalhos para a actualização da Carta Arqueológica realizados em 2009, regressámos ao local, para monitorizar as ocorrências conhecidas e inventariadas, verificando-se a expansão da pista de Aeromodelismo, mais a sul, para a área do Locus I, e a presença à superfície de uma mancha de combustão, que se encontrava exposta, em risco de destruição total (Figura 5).

Determinada a sua vulnerabilidade e exposição a ameaças várias, como a erosão eólica e as resultantes da sua localização numa pista de Aeromodelismo, um caminho em terra batida que separa os Locus I e II e a zona de extracção de areias na área do Locus II, realizámos uma sondagem no Locus I, para registar e caracterizar a estrutura de combustão que se observava à superfície e a prospecção sistemática intensiva, por quadrículas numa área circunscrita e adjacente à Sondagem 1 e nas áreas de maior dispersão de materiais.

\section{A INTERVENÇÃO ARQUEOLÓGICA}

A presença da estrutura de combustão determinou a localização da sondagem 1 (Si), implantada numa área total de $4 \mathrm{~m}^{2}$, distribuída por uma malha de $1 \mathrm{~m}$ $\mathrm{x}$ I m, e orientada a Norte, a que se seguiu a marcação da quadricula das áreas a prospectar, partindo desta sondagem.

Começámos por limpar e remover o depósito superficial arenoso e orgânico, com presença de materiais. Seguidamente, prosseguiu-se com a delimitação e definição da estrutura de combustão e contextos associados, bem como dos registos gráficos, fotográficos e topográficos. Todos os sedimentos foram removidos manualmente e crivados com malha fina.

A intervenção realizada não permitiu uma leitura segura do sítio, parecendo-nos que a mancha de combustão poderia tratar-se de uma realidade mais recente, que perturbou o nível arqueológico - correspondente ao sedimento superficial -. Não tem, além dos materiais presentes no topo da [U.E. 3], qualquer evidência de ocupação associada aos contextos arqueológicos. Os termoclastos recolhidos não são provenientes deste contexto. (Figuras 6 e 7 ). A escavação da Si terminou no Plano 5, no estrato correspondente ao Paleosolo [U.E. 5], sem presença de espólio ou estruturas associadas, a o.6o m de profundidade, registando-se no total, seis unidades estratigráficas distintas, mas apenas três reuniam escassa informação sobre a ocupação antrópica, cuja leitura se revelou muito condicionada pela exposição aos efeitos da erosão nos contextos e das perturbações ocorridas no local. A sequência estratigráfica era a seguinte:

- [U.E. o] - Sedimento superficial, com alguma vegetação rasteira, arenoso com granulometria fina, de cor amarelo-branco claro. Registou-se a presença de espólio;

- [U.E. 1] - Estrutura. Mancha de combustão, formando um covacho subcircular, aberto no paleosolo. Cortava o estrato geológico [U.E. 2] e era preenchido pelo sedimento [U.E. 3];

- [U.E. 2] - Estrato arenoso de grão muito fino, de cor amarela e húmido. Corresponde ao paleosolo, sem espólio associado. Profundidade 
atingida o,5om. A mancha de combustão [U.E. 1] assentava e cortava esta unidade que lhe servia de base;

- [U.E. 3] - Sedimento cinzento, arenoso e húmido, que preenchia a mancha de combustão [U.E. 1], composto por cinzas. Não tinha fauna associada e apenas se registava espólio no topo desta unidade, a sua percentagem diminuía em profundidade. Esta unidade era visível à superfície, a que lhe encostava a [U.E. o]; preenchia o covacho [U.E. 1] e sobrepunha-se à [U.E. 4];

- [U.E. 4] - Base do covacho. Sedimento amarelo, com manchas escuras, pontuado por cinzas e raros carvões de pequeníssima dimensão. Assentava sobre a [U.E. 2];

- [U.E 5] - Sedimento amarelo claro, arenoso de grão fino, que surgiu sob a [U.E. 2]. Não apresentava espólio, nem carvões associados;

- [U.E 6] - Pequena bolsa de uma raíz preenchida por areia fina, com algumas cinzas.

Concluída a escavação, nos dias seguintes avançou-se com os trabalhos de prospecção no Locus I e II. Como referimos, a quadricula de referência espacial foi organizada a partir da S1, distribuída ao longo de $3.400 \mathrm{~m}^{2}$ (Locus I - $2.720 \mathrm{~m}^{2}$ e Locus II $-680 \mathrm{~m}^{2}$ ), com quadrados de $2 \mathrm{~m} \mathrm{x} 2 \mathrm{~m}$ coincidentes com a área de maior concentração de materiais, que foram integralmente recolhidos. À superfície era visível a diversidade artefactual sendo notória a presença de raros termoclastos, de núcleos prismáticos (alguns esgotados) e produtos debitados maioritariamente em sílex e quartzito. A sua densidade vai diminuindo à medida que nos aproximamos do caminho de terra batida que separa as duas áreas, que distam uma da outra, aproximadamente $100 \mathrm{~m}$. Neste intervalo não foi individualizada a presença de espólio. (Figura 8) Nas áreas analisadas, o sedimento que aflora à superfície é pouco espesso, resultado da erosão e afectação que a área sofreu. Esta área denominada por "Pinhal Santos Jorge» à data da intervenção estava desflorestada e em pousio, com escassa vegetação rasteira, que oferecia uma boa leitura do solo, composto por um sedimento fino e muito arenoso, a que se associavam os materiais arqueológicos, seguido do paleosolo também arenoso e de grão fino.

A fraca conservação dos contextos arqueológicos que documentam a ocupação deste local deve-se sobretudo à exposição a fenómenos naturais e, em períodos mais recentes, às acções relacionadas com a esporádica extracção de areias (Locus II) e o desa- terro de algumas áreas, para a construção da pista de Aeromodelismo e acesso a este equipamento, adjacente ao Locus I.

\section{PRIMEIRAS LEITURAS, ALGUMAS QUESTÕES E INTENÇÕES FUTURAS}

Os territórios explorados pelos grupos humanos entre Tejo e Sado, em consequência do aquecimento climático registado a partir de 10.000 a.n.e. e dos efeitos da transgressão flandriana, transformam-se, tornam-se mais circunscritos em extensão e recursos. A capacidade de adaptação ao meio ambiente, dos grupos de caçadores-recolectores pós-glaciares é reconhecida, na prática de uma economia de subsistência de largo espectro, explorando zonas com uma diversidade de recursos alimentares (Silva e Soares, 2016; Soares e Silva, 2008), que implicariam pouco esforço, através da recolecção, da pesca e da caça de pequeno e médio porte, actividades que teriam expressão no quotidiano destes grupos interestuarinos.

Os dados que dispomos desenham uma ocupação sazonal, junto às margens de importantes cursos de água, por um grupo humano, muito provavelmente num período de curta duração para exploração do território, com excelentes condições de mobilidade e uma cultura material, ainda com aparente tradição magdalenense, onde se destaca a exploração de três tipos distintos de matéria-prima, o quartzito, o quartzo e o sílex, assumindo a indústria lamelar e laminar em sílex, particular expressão.

Não encontramos nos contextos associados ao sítio indícios de produção e armazenagem de alimentos, nem a exploração de recursos marino-estuarinos (recolhidos apenas dois pequenos restos de concha) ou consumo de cinegéticos. A reduzida área de amostragem intervencionada no ano de 2009 e, a ausência destes recursos, talvez degradados pela acidez dos solos arenosos e a erosão a que o sítio esteve exposto, não nos permitem avançar com considerações sustentadas sobre o modelo de gestão e consumo praticados.

No conjunto artefactual maioritariamente recolhido à superfície, não estavam presentes recipientes cerâmicos (também ausentes na Si), registando-se abundantes materiais em pedra lascada nomeadamente, as lascas obtidas sob quartzos e quartzitos, e a existência de uma indústria lamelar e laminar em sílex, para a produção de produtos alongados 
e de utensílios. Os restos de talhe, as peças de descorticagem e reavivamento de blocos a debitar, conjugados com a presença de núcleos esgotados e de material debitado, confirmam a prática de talhe de matéria-prima regional e exógena (Figuras 9 e 10).

Nesta leitura bastante preliminar que fazemos, parece-nos evidente que a exploração do quartzo e do quartzito aplicaria uma estratégia expedita para a produção de utensilagem de fundo comum, sobretudo de lascas retocadas ou em bruto para uso circunstancial (Carvalho, 1998b; Soares, 2013 e Neves, 2013). Contrariamente, a exploração do sílex (algum de excelente qualidade e proveniente de áreas distantes do Poceirão I) foi dirigida para a produção de suportes alongados e utensílios (estando ausentes no conjunto, os geométricos), com presença de lascas e dos suportes lamelares e laminares (os últimos em menor número) aproveitando-os quase integralmente, e em alguns casos, submetendo-os ao pré-tratamento térmico, obtendo-se um talhe mais cuidado e um melhor aproveitamento.

A presença de materiais arqueológicos à superfície e da reduzida potência estratigráfica registada podem denunciar uma ocupação sazonal, extensível ao longo desta plataforma situada próxima de importantes cursos de água, que facilitaria o acesso a recursos abundantes e à comunicação fluvial.

Partindo dos dados disponíveis e na ausência de matéria que possibilitasse a obtenção de datações absolutas, o Poceirão I, ocupado por grupos de caçadores-recolectores parece enquadrar-se crono-culturalmente, num momento inicial do Mesolítico (entre 10.000 a 7.000 a.n.e.) ou mesmo anterior, no final do Paleolítico Superior.

Os dados arqueológicos que apresentamos, resultam maioritariamente de observações e recolhas de superfície e como tal, a sua interpretação condicionada pelas limitações que lhe são oriundas é realizada com as necessárias reservas, obrigando-nos a prosseguir uma reflexão e estudo sobre estas comunidades de caçadores-recolectores, que ocuparam o território de Palmela, de que tão pouco conhecemos. Recentemente, quando começámos a redigir este texto, visitámos o local, agora com bastante coberto vegetal, e lamentavelmente percebemos, que a pequena área de extracção de inertes, que havíamos registado em anos anteriores, expandiu-se consideravelmente, e destruiu uma parte da área do Locus II (prospectada nos anos de 2005 e 2009). Para poente, no Locus I, confirma-se o crescimento da Pista de
Aeromodelismo, que se localiza agora sobre a área escavada em 2009 (sondagem 1). Procuramos neste momento averiguar a condição da situação verificada, diligenciando para que se proceda a uma avaliação dos impactos ocorridos e a pertinência de desenvolver adequadas medidas de salvaguarda arqueológica. Por fim, termino com um agradecimento ao João Nunes e ao Marco A. Andrade pelo apoio e disponibilidade no esclarecimento de algumas questões (por vezes, muitas), na elaboração dos desenhos dos materiais e no tratamento gráfico das imagens usadas no texto.

\section{Palmela, Junho de 2020}

\section{BIBLIOGRAFIA}

CARVALHO, A. F. (1998b) - Talhe da pedra no Neolitico antigo do Maciço Calcário das Serras d'Aire e Candeeiros (Estremadura Portuguesa). Um primeiro modelo tecnológico e tipológico. Textos Monográficos. Lisboa.

DAVEAU, Suzanne (1980) - Espaço e Tempo. Evolução do ambiente geográfico de Portugal ao longo dos tempos pré-históricos. Clio. Lisboa. 2, pp. 13-37.

FERNANDES, Isabel Cristina Ferreira; SANTOS, Michelle Teixeira (2012) - Carta Arqueológica do Concelho de Palmela. In Palmela Arqueológica no contexto da região interestuarina Sado-Tejo. Palmela, pp. 11-24;

NEVES, César (2013) - A Evolução do Processo de Neolitização numa paisagem estuarina: a ocupação do Monte da Foz 1 (Benavente, Portugal). In Pré-História das Zonas Húmidas, Setúbal Arqueológica. Setúbal 14, pp. 123-144.

SOARES, Joaquina (2013) - Caçadores-recolectores semi-sedentários do Mesolítico do paleoestuário do Sado (Portugal). In Pré-História das Zonas Húmidas, Setúbal Arqueológica. Setúbal 14, pp. 13-56.

SILVA, Carlos Tavares da; SOARES, Joaquina (2016) - The Pleistocene-Holocene transition on the portuguese southwest coast. A zero stage of social complexity? In Social Complexity in a long-term perspective (Session B15). Setúbal Arqueológica. Setúbal 16, pp. 21-40;

SOARES, Joaquina; SILVA, Carlos Tavares da (2008) - Camarral e Casal da Cerca: Sítios Pré-Históricos do Concelho. Acampamento Epipaleolítico do Camarral (Volta da Pedra/ Palmela). Roteiro da Exposição Palmela Arqueológica. Espaços, Vivências, Poderes. Palmela, pp. 21-25;

ZBYSZEWSKI, Georges; FERREIRA, Octávio da Veiga (1968) - Carta Geológica de Portugal: notícia explicativa da Folha 35-C, escala 1/50 ooo. Lisboa: Serviços Geológicos de Portugal. 


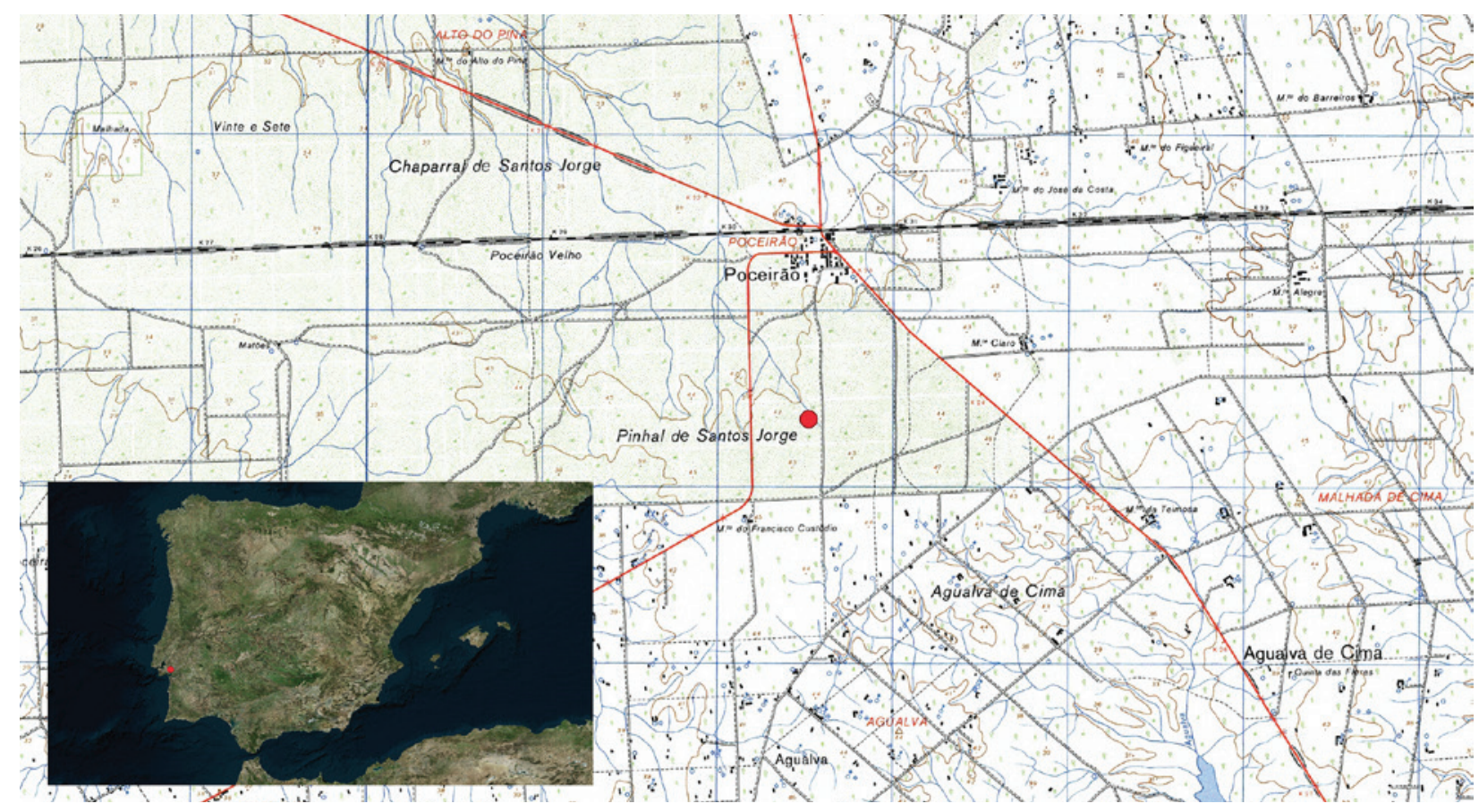

Figura 1 - Localização sobre excerto da Folha n.ํ4 44 da CMP, à escala 1:25.0oo. 


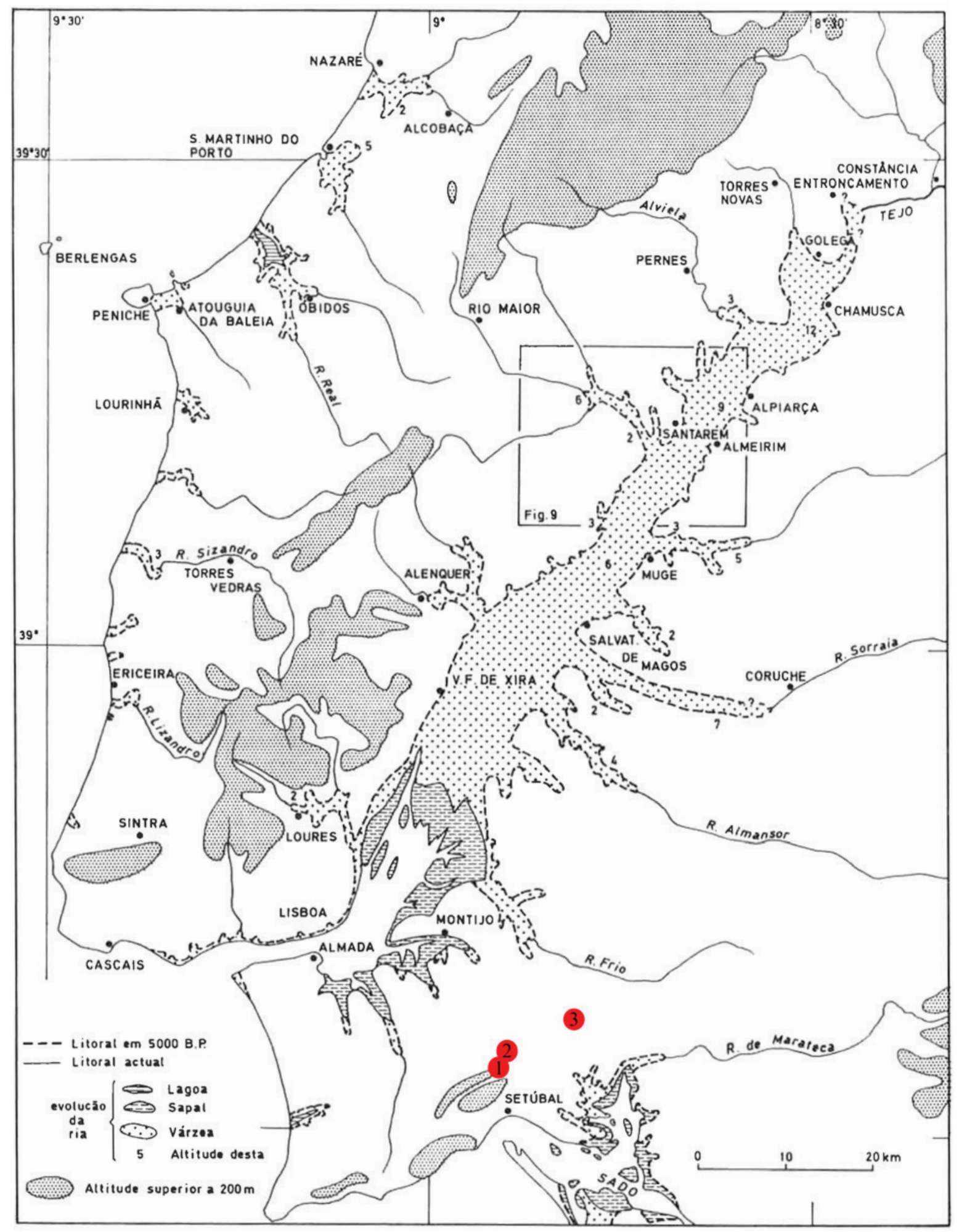

Figura 2 - Enquadramento na região interestuarina Tejo-Sado: 1. Casal da Cerca; 2. Camarral; 3. Poceirão I (base cartográfica adaptada: Daveau, 1980:26). 


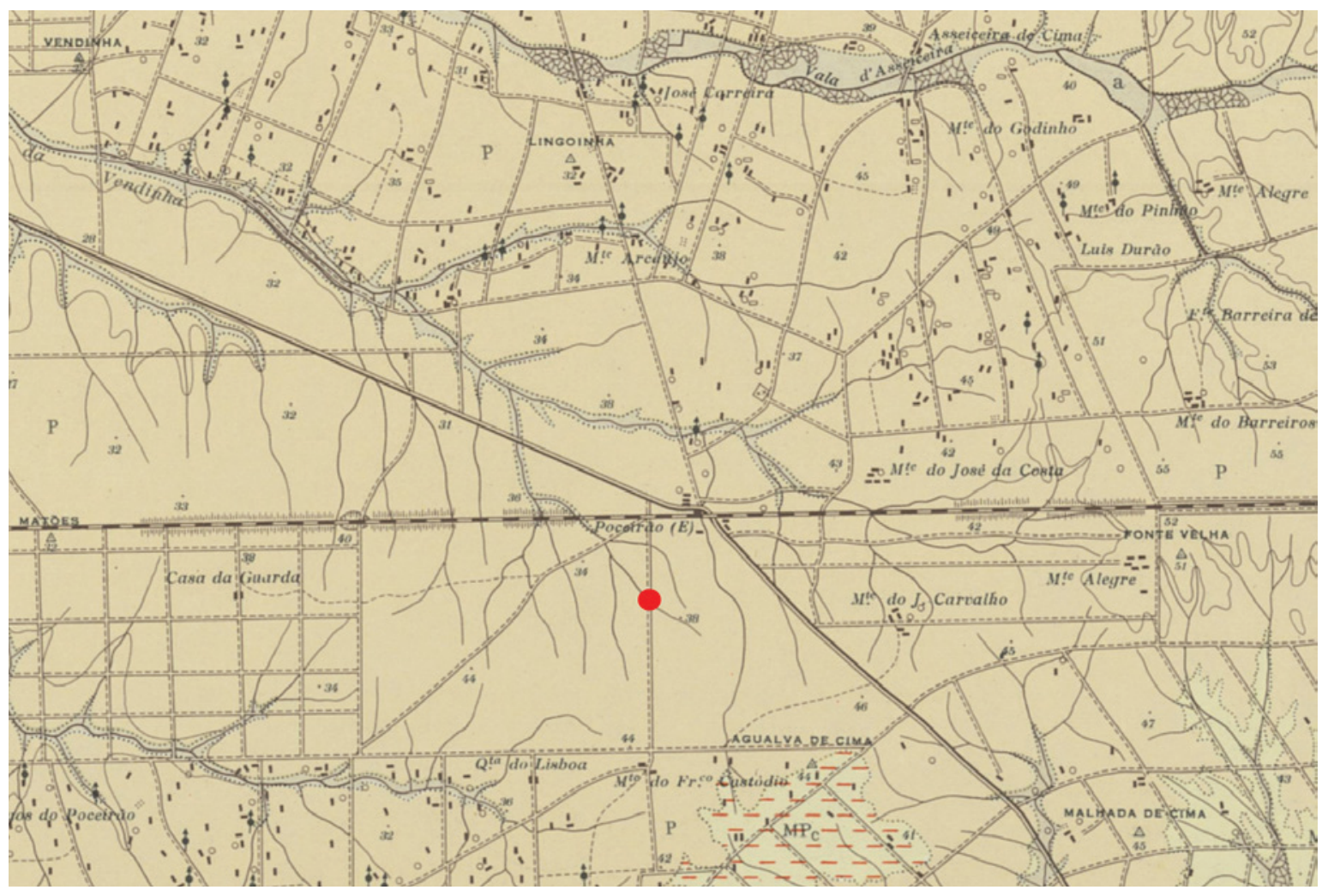

Figura 3 - A Geologia do Poceirão I - excerto da Carta Geológica de Portugal, Folha 35-C, 1:50.ooo, Serviços Geológicos de Portugal.

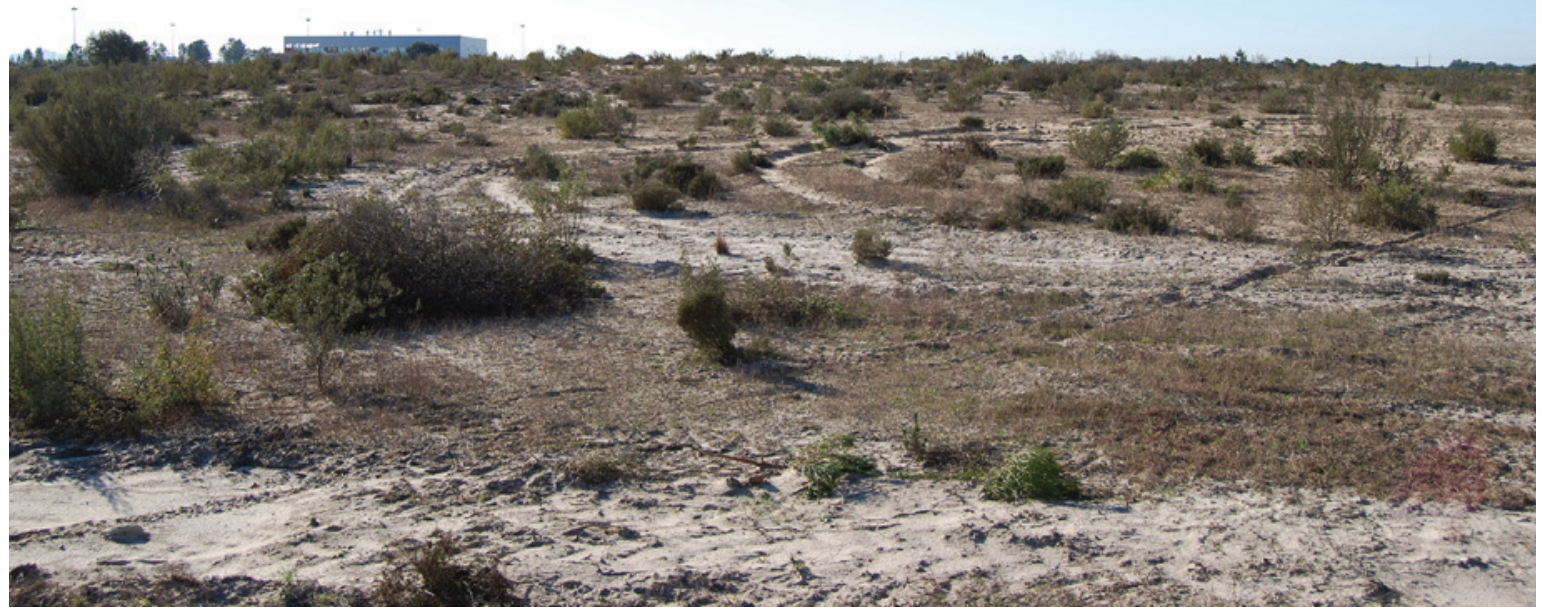

Figura 4 - Vista geral da plataforma do Poceirão I. 


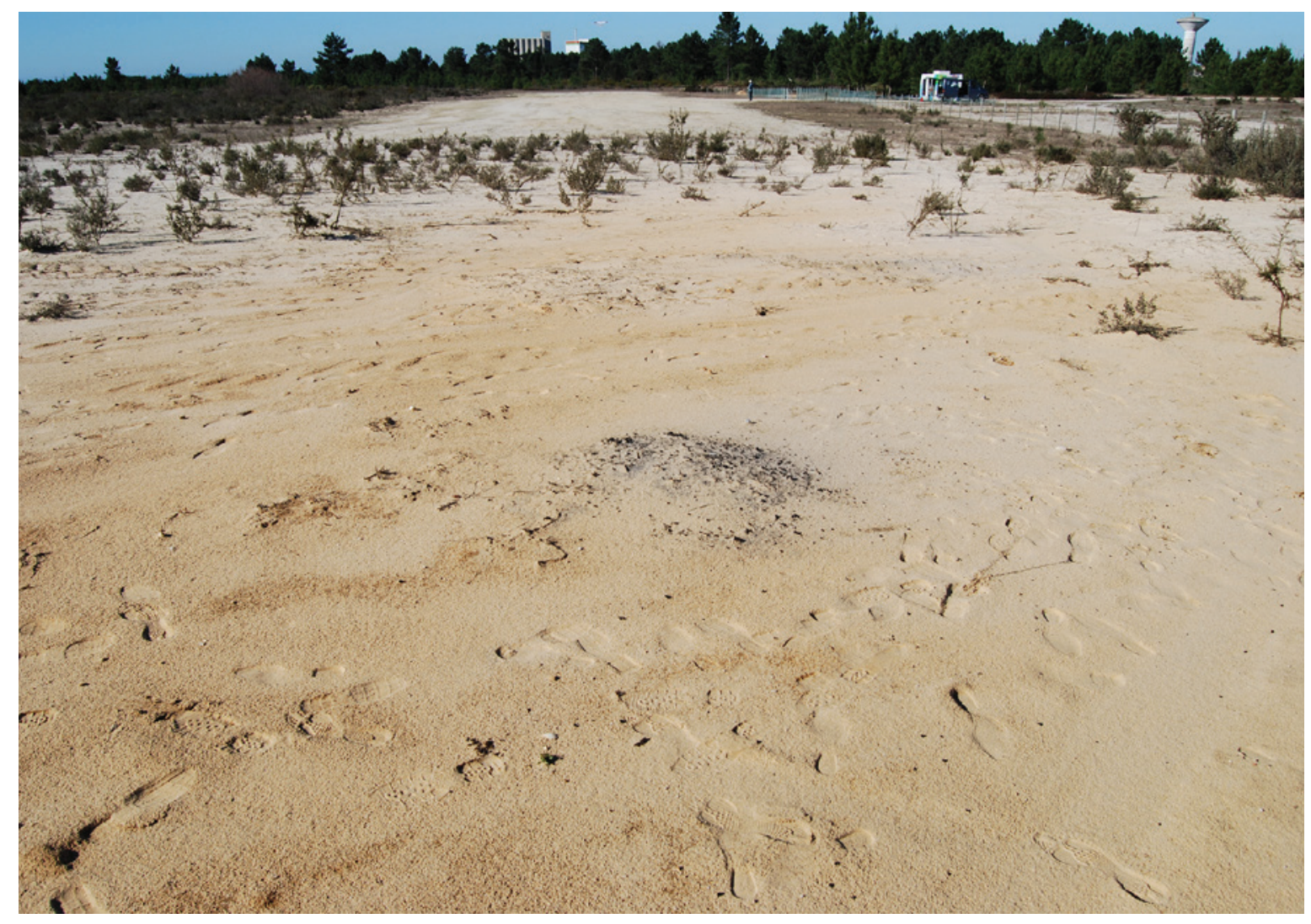

Figura 5-Área do Locus I e a Pista de Aeromodelismo, com a mancha de combustão visível ao centro da imagem.

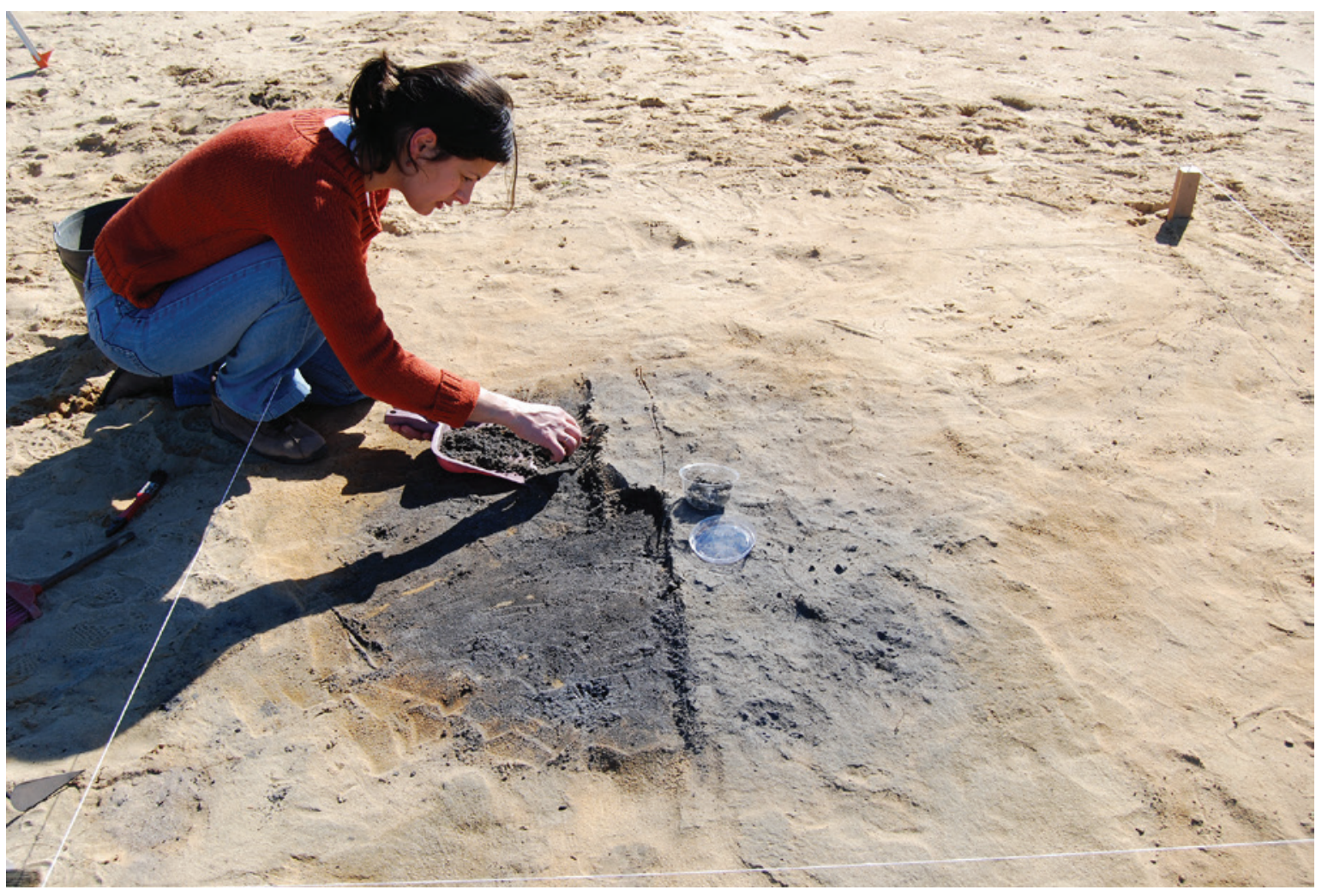

Figura 6 - Sondagem 1 - mancha de combustão. 


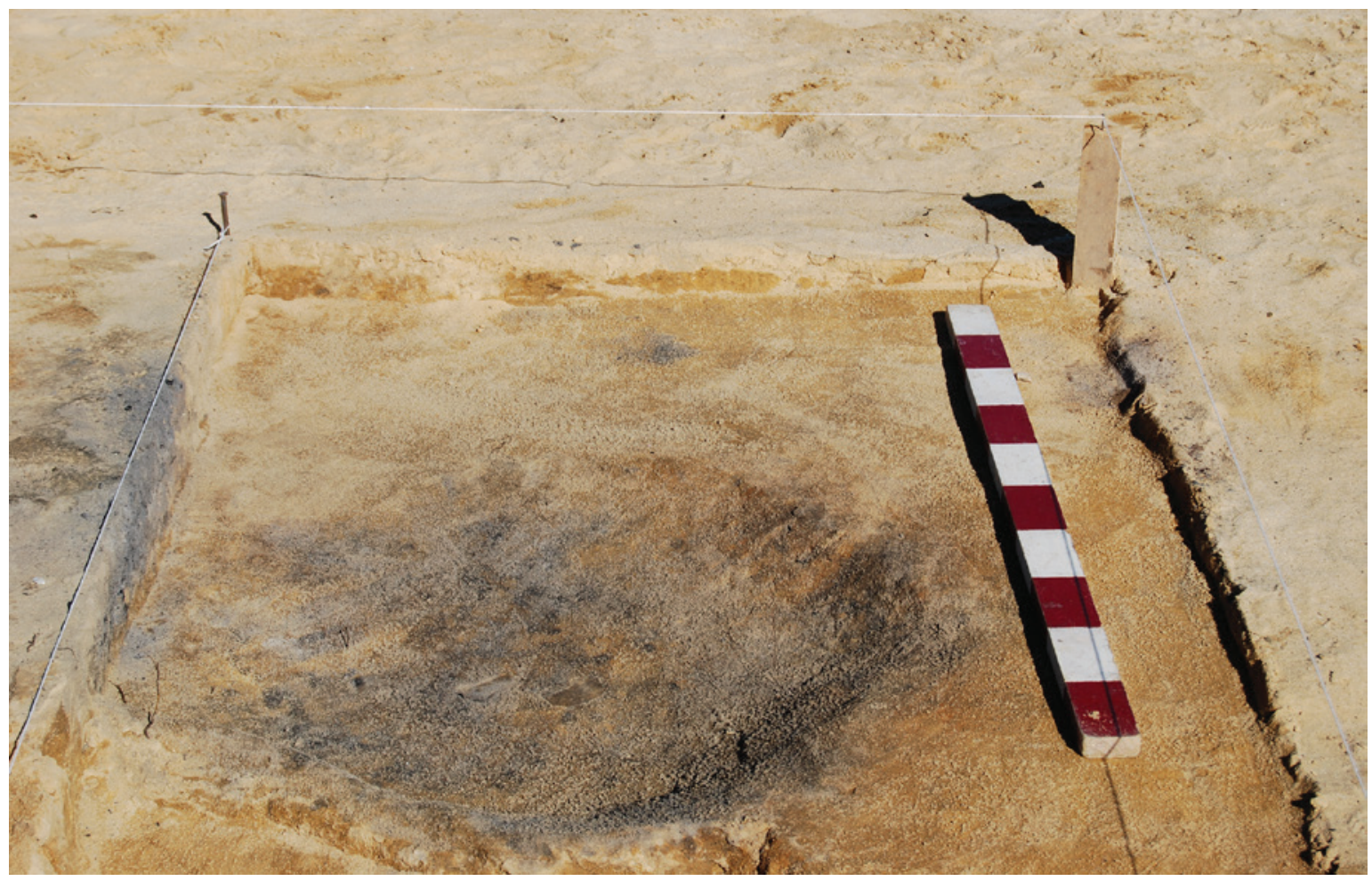

Figura 7 - Escavação do Plano 4. Pormenor do negativo da estrutura de combustão [U.E. 1].

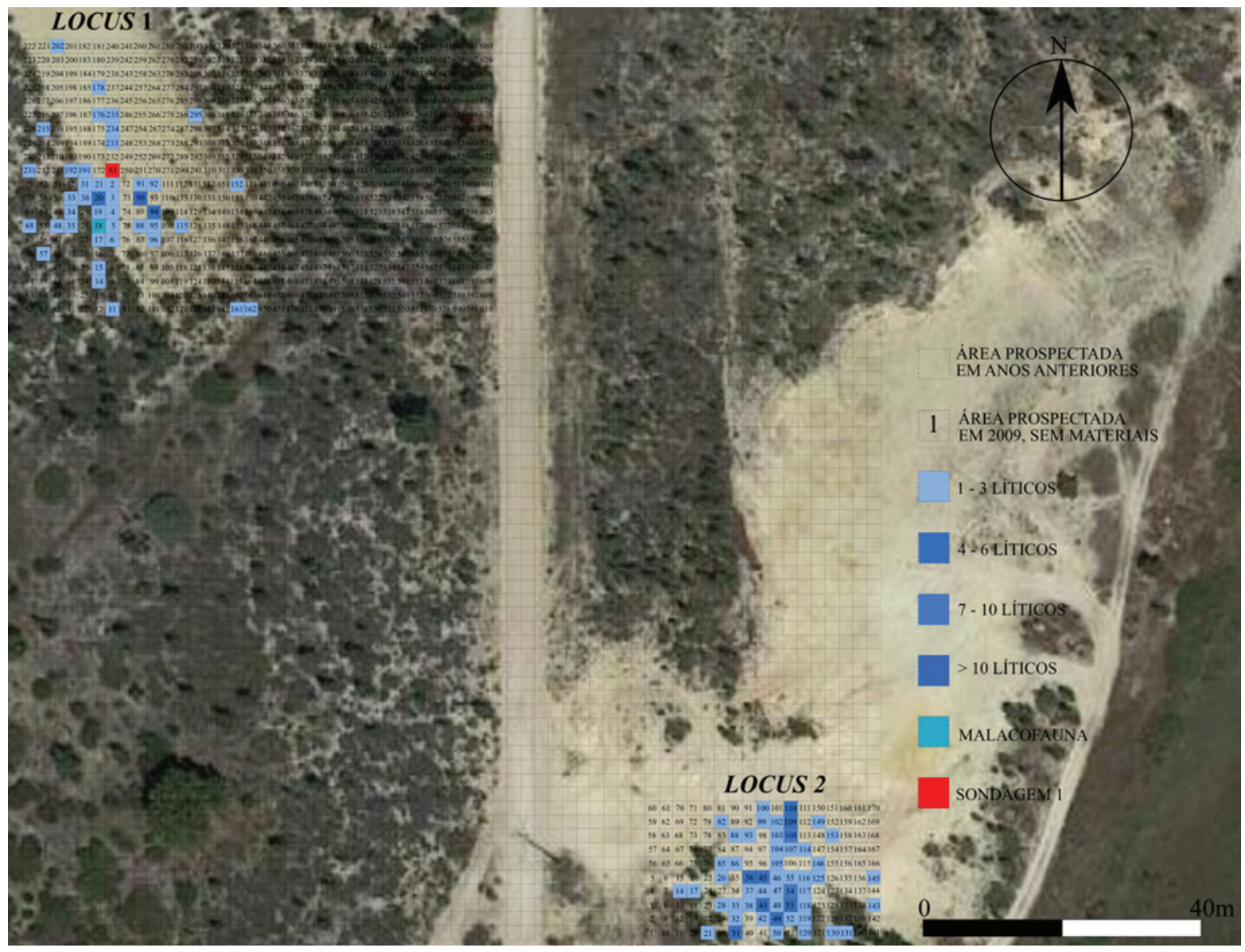

Figura 8 - Distribuição espacial dos materiais à superfície (Locus I e II). 

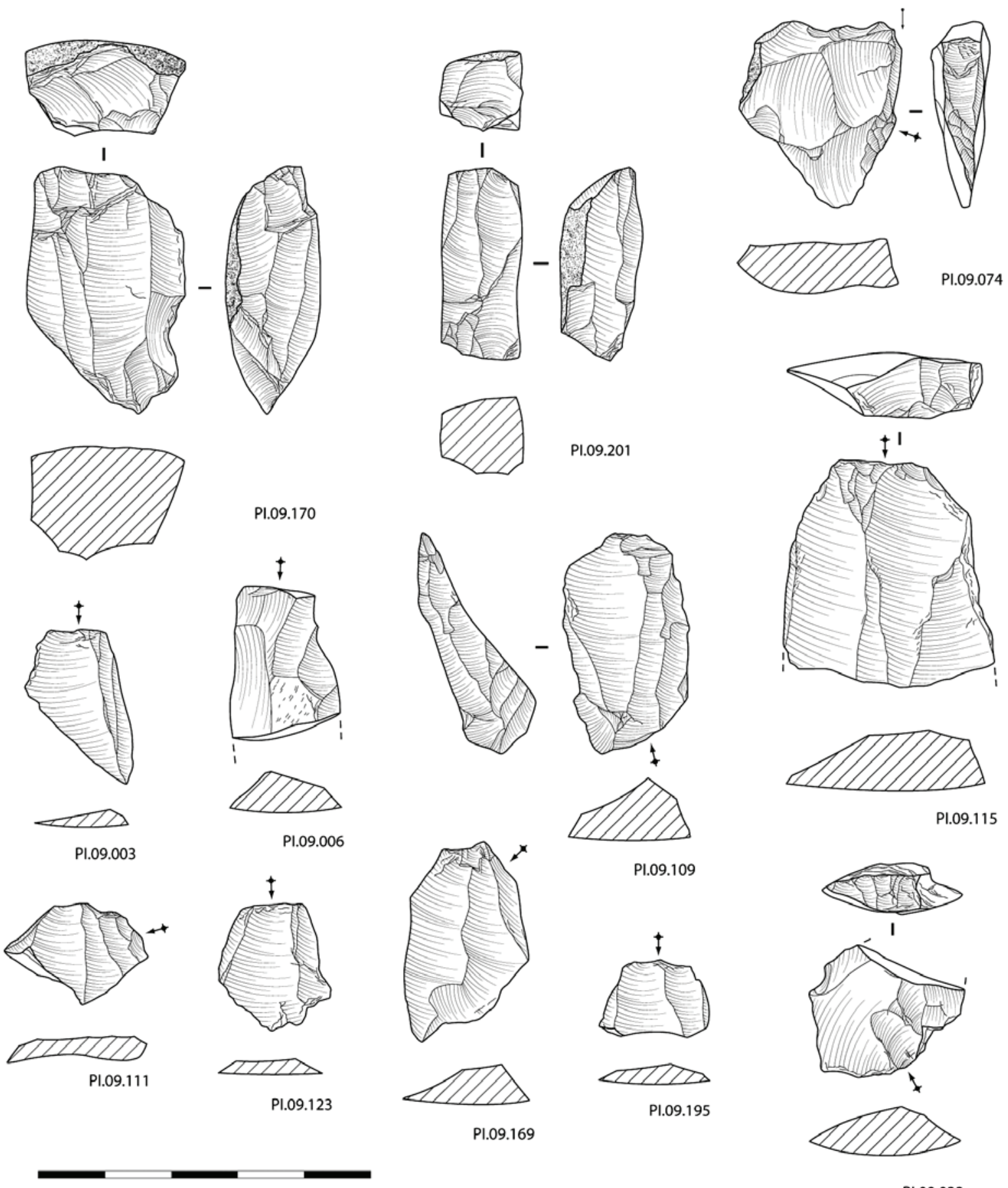

PI.09.115
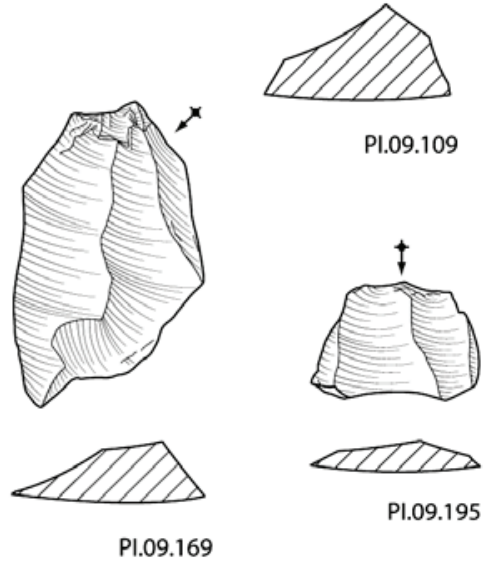

PI.09.195

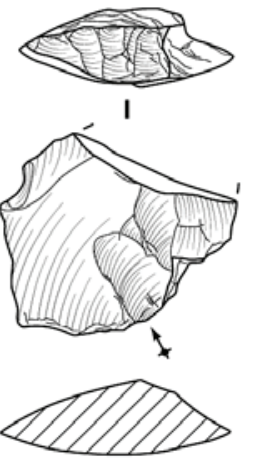

PI.09.033

Figura 9- Pedra lascada (sílex e quartzito): núcleos, material de preparação e resíduos de talhe (Desenho de Marco António Andrade). 

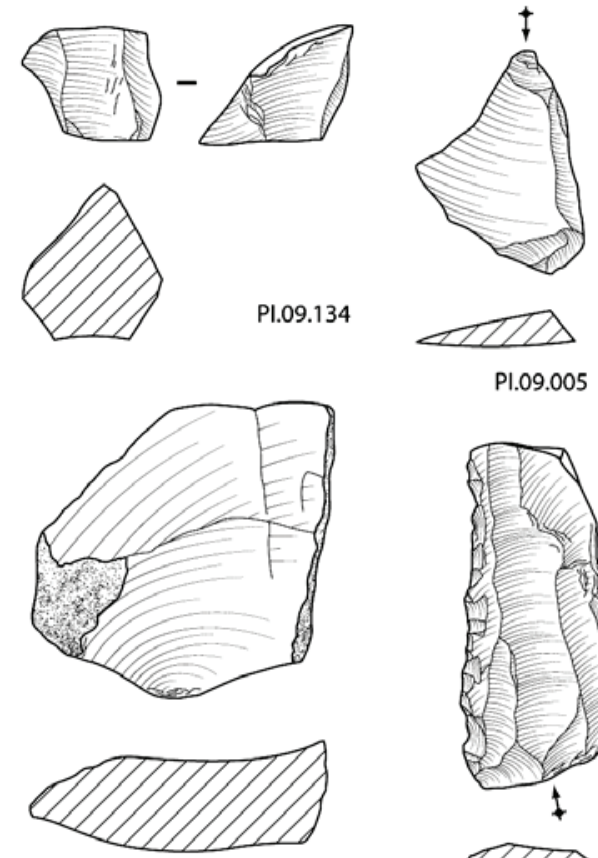

PI. 09.200
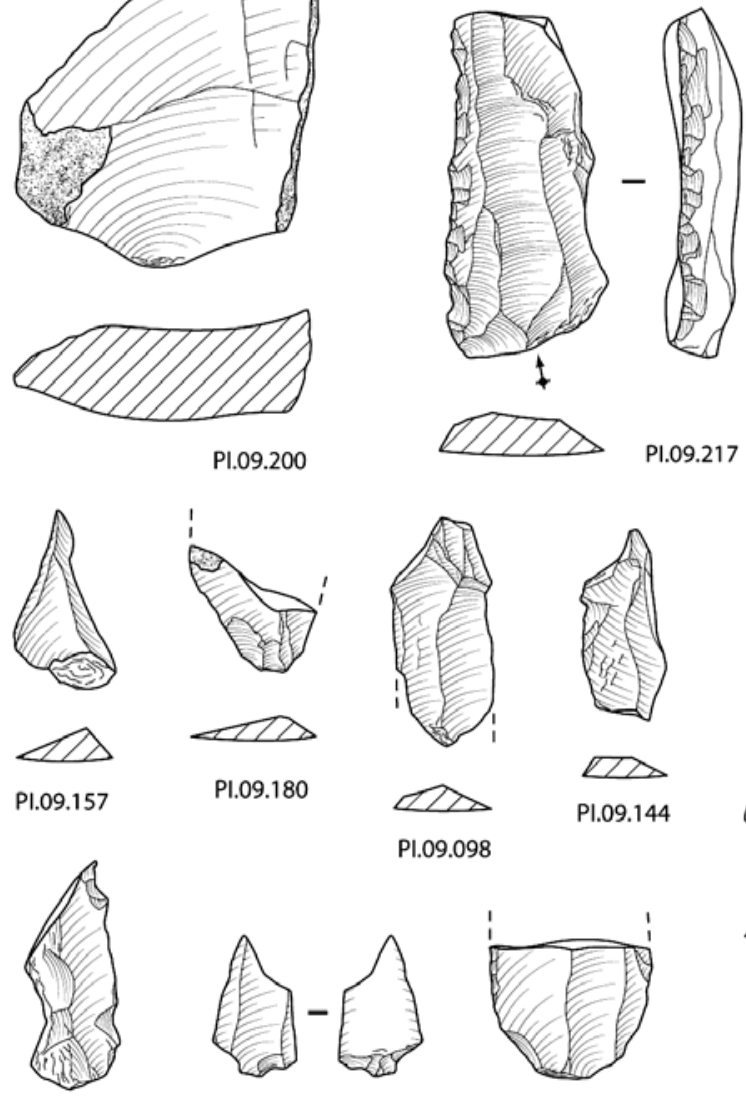

$\begin{array}{ll}\text { Pl.09.098 } & \text { Pl.09.144 } \\ & \end{array}$ P1.09.098

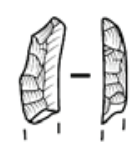

$\Delta$
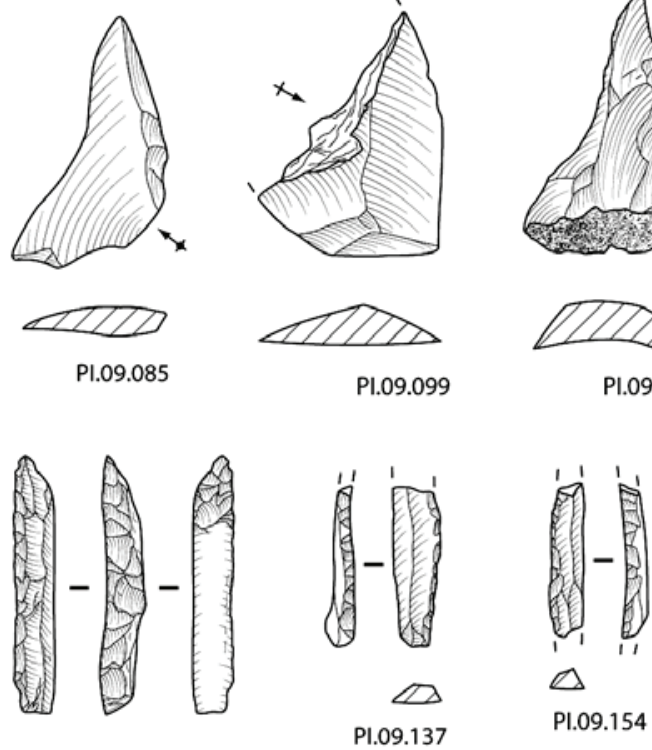

$\triangle$
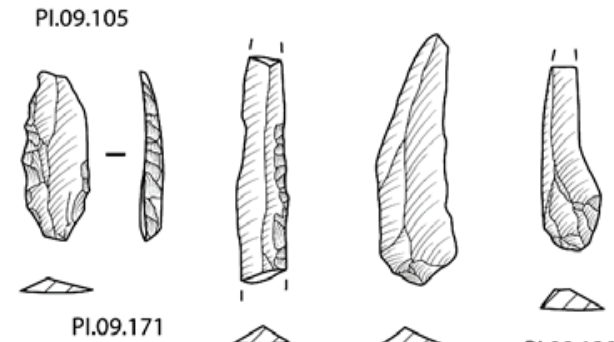

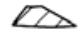

PI.09.138
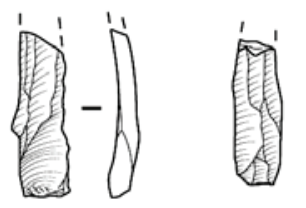

PI.09.158

PI.09.126

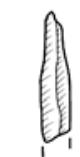

$\overbrace{\text { PI.09.066 }}$

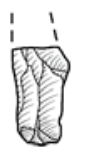

$\infty$

PI.09.075
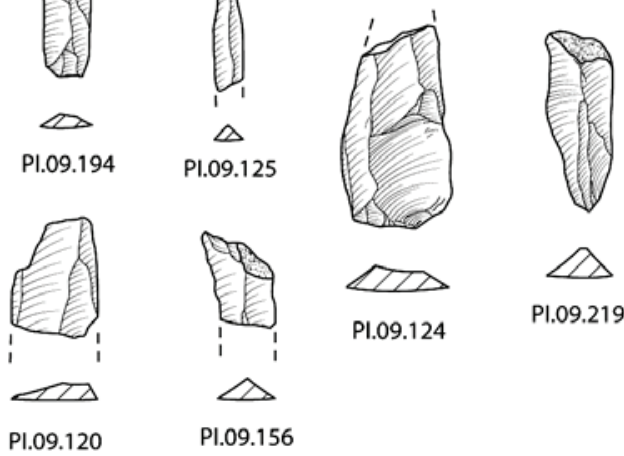

Figura 10 - Pedra lascada (sílex e quartzito): utensílios e lamelas. (Desenho de Marco António Andrade). 


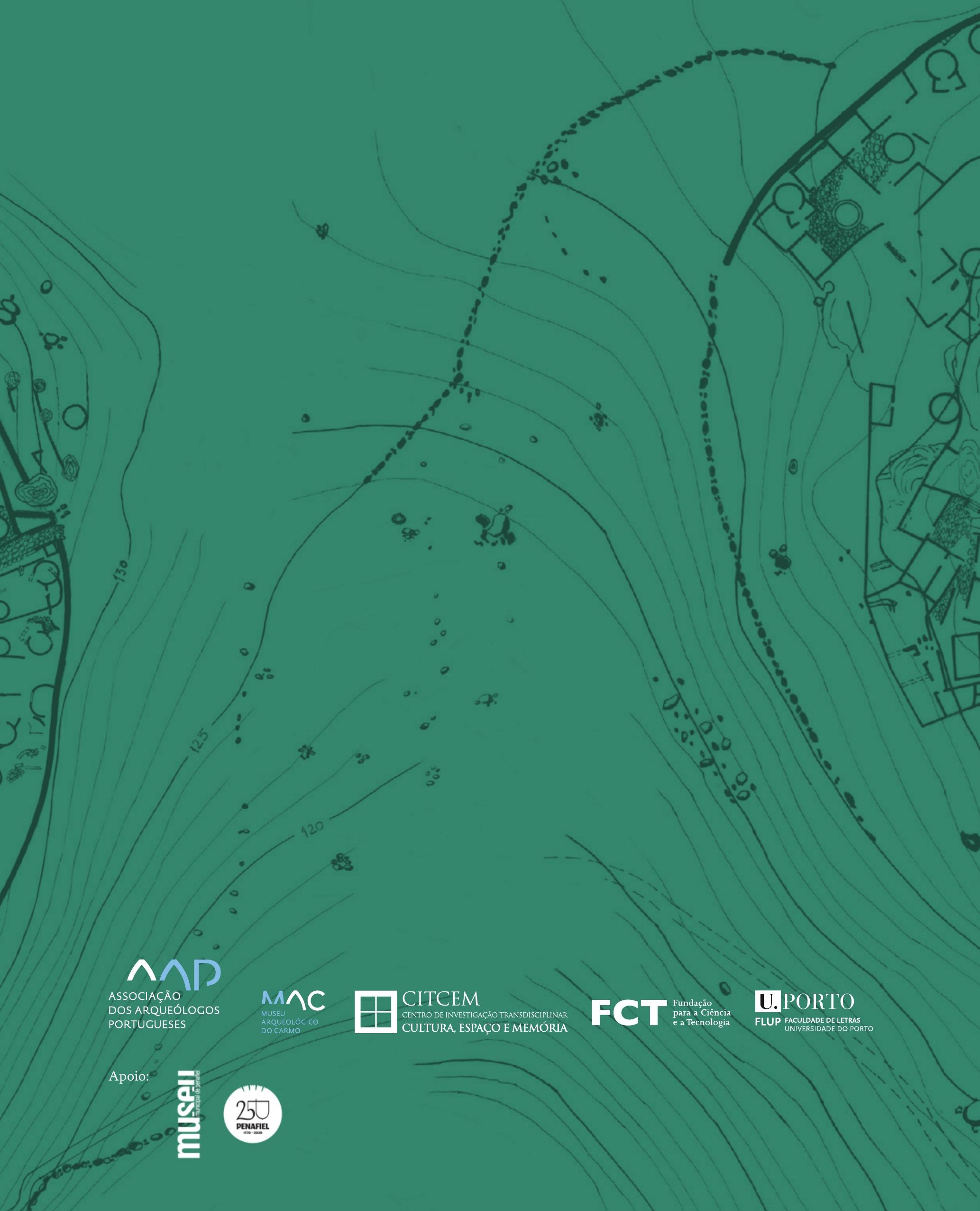

